\title{
Михаил Саенко
}

Институт славяноведения Российской академии наук, Москва

\section{Праславянское *pepelъ/*popelъ: исходная форма и этимология}

Prispevek obravnava zemljepisno razširjenost in zgodovinski razvoj praslovanskega *popelъ in *pepelı v slovanskih jezikih. Analizirane so štiri hipoteze o etimologiji praslovanskih oblik: 1. delna podvojitev glagolskega korena *pel(H)- 'goreti', 2. predponska tvorjenka iz korena *pel(H)- 'goreti', delna podvojitev korena *pelH- 'fin prah, moka' in 4. hipoteza o nostratičnem izvoru leksema.

The article examines geographical and historical relationships between descendants of the forms *popelb and *pepels 'ashes' in the Slavic world and analyses four basic etymologies of this word (reduplicated derivative of *pel $(H)$ - 'to burn', prefixed derivative of *pel(H)- 'to burn', derivative of *pelH- 'fine dust' and Nostratic etymology).

1 Позднепраславянское обозначение «пепла» достаточно уверенно восстанавливается как *pëpelъ / *pöpelъ. Было выдвинуто как минимум 4 различных версии этимологии этого слова, но в научной среде отсутствует консенсус относительно того, какая из них является более вероятной. В данной статье мы попытаемся подробно проанализировать соотношение вариантов *pepels и *popelb, а также, что непосредственно из такого анализа вытекает, определить, какая из предложенных этимологий является самой предпочтительной.

2 Уже Й. Добровский обратил внимание на разницу в рефлексах этого слова. В своей классификации славянских языков он перечисляет разницу между попел и пепел среди прочих черт отличающих «Idioma ordinis primi» (южные и восточные в современной классификации) от «Idioma ordinis secundi» (западные) (Dobrowsky 1822: III-IV).

Если мы более подробно рассмотрим распределение континуантов *popelъ и *pepelъ в славянских языках, то сразу бросается в глаза, что в западнославянских языках представлено исключительно *popelъ ${ }^{1}$.

1 Литературные языки: пол. popiót, чеш. popel, слв. popol, кашуб. pòpiót, полаб. püpel, в.-луж. popjet, н.-луж. popjet. 
При обращении к восточнославянской группе 2 видно, что континуанты *popelъ преобладают на украинской, белорусской и южнорусской территории. Однако форма пєпєль дважды встречается в белорусском памятнике XVII века (ГСБМ 24: 81). В севернорусском наречии преобладает *pepelb, но островками встречается и *popelъ. Так, Общеславянский лингвистический атлас фиксирует континуанты *popelъ в следующих пунктах: Верхне-Ерогодский Починок, Вологодская область (пункт 602, 'pop'et); Елинская, Архангельская область (пункт 596, 'p'ep'el / 'pop'et); Голодяйка, Ярославская область (пункт 640, 'рор'еt); Осташово, Новгородская область (пункт 610, 'p'ep’ət / 'pop'ət); Меглино, Тверская область (пункт 677, 'pop'et); Шушелово, Новгородская область (пункт 656, 'p'ep'it / 'pop'it); Курлово, Владимирская область (пункт 754, pa'p'ot / 'pop'it) (ОЛА, карта 9). Кроме того, мы находим в деревне Деулино формы nón’ форму попел и Словарь русских народных говоров (СРНГ 29: 301).

В южнославянских языках ${ }^{3}$ тоже присутствуют оба варианта, причём в настоящее время доминируют континуанты *pepels, а *popelъ встречается только на периферии. По данным Общеславянского лингвистического атласа, *popelъ фиксируется в ряде словенских диалектов: Криж / Санта-Кроче, провинция Триест (пункт 3, po'pieus); Шмартно, община Брда (пункт 4, papè:u) Хорьюл, община Хорьюл (пункт 8, раре̣:

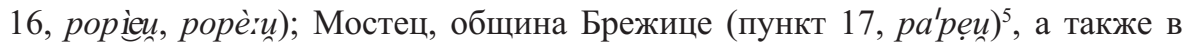
чакавском диалекте: Жминь (пункт 22, 'popel); Добринь (пункт 24, 'pope:l); Рукавац, община Матульи (пункт 25, 'pope:l). Следует также упомянуть форму риріёи из словенского бовецкого диалекта (Ivančič Kutin 2007: 75), pöpel из чакавского диалекта деревни Орбаничи (Kalsbeek 1998: 524), nónạл из говора деревни Лехово (Эгейская Македония) (Видоески 1994: 44).

По данным Этимологического словаря славянских языков, различные источники также отмечают следующие диалектные южнославянские диалектные формы: рорео, рореl, pöpel, papiéú

Однако, вероятно, ранее континуанты *popelъ были распространены значительно шире. Так, в древнейших памятниках старославянского языка более

2 Литературные языки: рус. пе́nел, укр. по́niл, бел. по́nел.

3 Литературные языки: болг. пе́nел, мак. пепел, схр. пёпео, слвн. pepẹl.

${ }^{4} \mathrm{~T}$. Логар предполагал, что - $a$ - в этом случае могло восходить к -е-. Однако других примеров для подобного фонетического изменения он не привёл. В то же время имеются хорошие примеры перехода предударного -о- в -a-: kakùoš, halò:pc, labò:da, klabà:sa (Fonološki opisi 1981: 57).

${ }^{5}$ Хотя в данном говоре имеются случаи изменения -e- в $-a$-, они не относятся к первому предударному слогу ('gu:sanca, 'kissau, 'and've'jst), зато есть примеры перехода предударного -o- в - $a-:$ - $k a^{\prime} k u \check{s}, d a^{\prime} m u{ }^{\prime}, k a^{\prime} k u t$ (Fonološki opisi 1981: 153).

${ }^{6}$ Автор выражает благодарность коллективу ЭССЯ и лично М. Н. Беловой за предоставления доступа к материалам готовящейся статья *pepelъ. 
распространено именно попєлъ: Зографское евангелие (2 вхождения), Мариинское евангелие (2 вхождения), Синайская псалтырь (1 вхождение), Супрасльская рукопись (1 вхождение); в то время как пєпєль появляется 3 раза и только в Супрасльской рукописи (Старославянский словарь 1994: 479).

Р. М. Цейтлин считает форму пєпєль в Супрасльской рукописи восточночноболгарской и увязывает её с другими элементами, привнесёнными в текст восточночноболгарским писцом (Цейтлин 1977: 289-290).

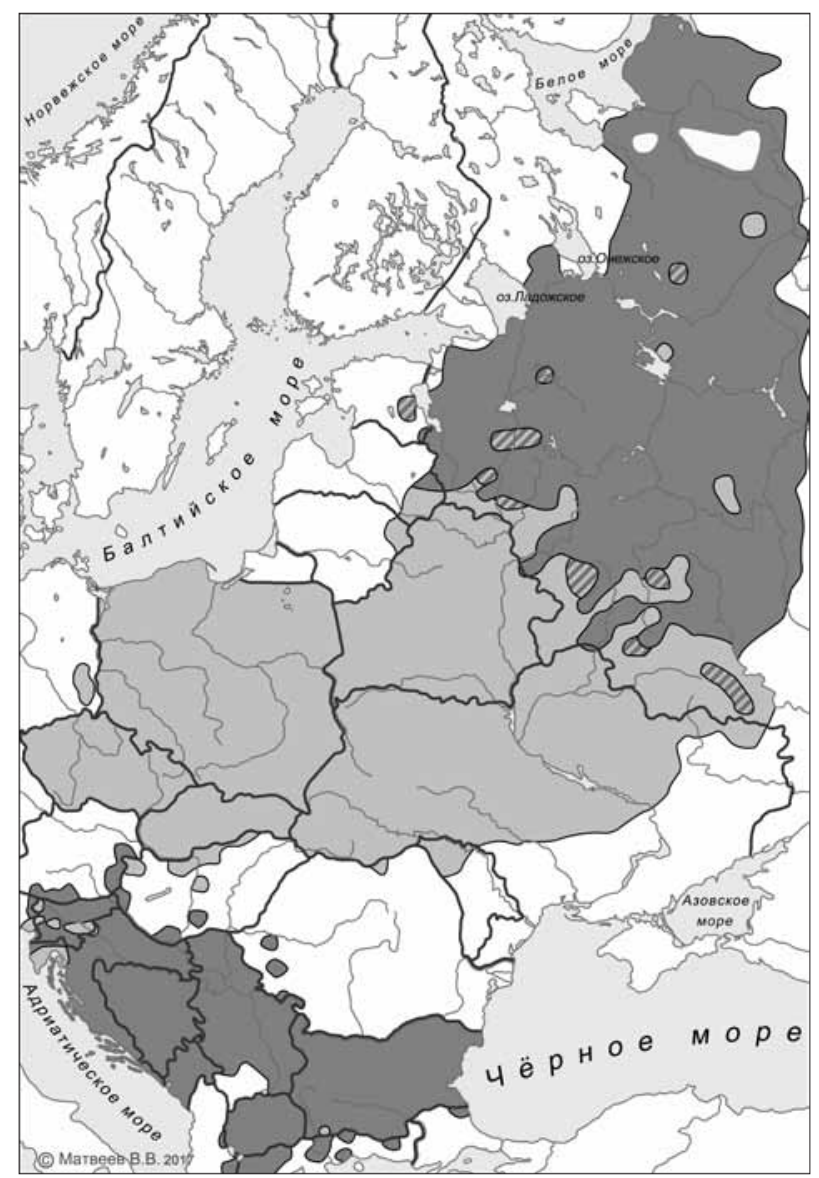

Рис. 1. Распределение континуантов *popelъ (светлый ареал) и *pepelъ (тёмный ареал) в славянских языках ${ }^{7}$,

${ }^{7}$ Автор благодарит В. В. Матвеева за карту.

${ }^{8}$ Карта не учитывает случаев, в которых основным обозначением пепла является слово, восходящее к иному корню (в частности, *lugъ и *watra). 
В более поздних памятниках попєль по-прежнему широко распространён: Psalterium Pogodinianum (Болгария, XII век); Psalterium e codice Lobkowicziano-Pragensi (Хорватия, XIV); Psalterium е codice Parisiensi (Хорватия, XIV); Apostolus Christopolitanus (Русь, XII); Praxapostolus Slepčensis (Болгария, XII); Paroemiarion Zacharianum (Русь, XIII); Glagolitica Iosephi Vajs (Хорватия, XIV-XV); Passio s. Viti (Русь, XII). Вариант пєпєль встречается в следующих памятниках: Tetra-evangelium Nicoljanum (Сербия, XV); Psalterium Bononiense (Болгария, XIII); Praxapostolus Achridanus (Болгария, XII); Praxapostolus Macedonicus (Болгария, XII); Praxapostolus Šišatovacensis (Сербия, XIV); Paroemiarion Grigorovičianum (Болгария, XII-XIII) (SJS 3: 168).

В чакавских говорах вариант popel ранее также был распространён шире, чем сейчас (Boryś 2007: 360-361).

Северорусские и южнославянские данные создают ощущение постепенного вытеснения варианта *popelъ формой *pepelъ, при котором континуанты *popelъ сохраняются только в отдельных островках. Что, на первый взгляд, свидетельствует в пользу большей древности формы *popelъ. Однако имеющиеся данные можно интерпретировать и следующим образом: как *pepels, так и *popelъ имелись уже в праславянском. После эпохи расселения славян в разных областях начинает побеждать один из вариантов: в западнославянских языках и части восточнославянского ареала безоговорочно выигрывает *popelb, в то время, как в южнославянских языках и второй части восточнославянских идиомов предпочтение отдаётся варианту *pepels, a *popels остаётся на периферии и в виде отдельных островков.

3 В разное время учёными было выдвинуто четыре противоречащих друг другу этимологии слова *pepelъ / *popelъ.

Первая версия считает *pepelz редуплицированным образованием от *polět $i$ «гореть» (Boryś 2005: 463; Derksen 2008: 395). Когнатами этого глагола являются также *paliti, *polneti, *palati, *polěno, *polmę (в альтернативной реконструкции *polmy). Отдельно стоит отметить форму *polpolati с редупликацией (чеш. plápolat «пылать»).

При таком этимологизировании исконной, разумеется, является форма *pepelъ, a *popelъ представляет собой вторичное образование.

Р. Дерксен полагает, что акцентологические данные можно интерпретировать как указывающие на то, что корень, лёгший в основу данного гнезда, следует восстанавливать как *pelh - (Derksen 2008: 390). Однако такая трактовка не является единственно возможной и необходимость реконструкции ларингала в данном случае остаётся под вопросом, поэтому в данной статье мы будем записывать этот корень как *pel(H)-9.

${ }^{9}$ Автор благодарит Р. Шептыньского за это и многие другие замечания, значительно поспособствовавшие улучшению статьи. 
Вторая версия отталкивается от той же основы, но первичной полагает форму *popelb, анализируемую как образование с приставкой *po- в значении «после». В таком случае внутренней формой является «то, что осталось после сожжения» (Machek 1968: 429-430).

В. Махек указывает на то, что в корне ожидался бы вокализм -о-, поэтому мы якобы имеем дело с перестройкой изначального *pelz, соответствующего литовскому (Machek 1968: 429-430). Однако среди девербативов с приставкой * ро- и значением результата действия есть и примеры праславянской древности с -е-вокализмом. Достаточно назвать *pogrebs, *pometъ и *poletъ. Особенно важно первое слово, полностью соответствующее *popelъ также и по ударению: *greti, *grebo > *pögrebъ > pус. по́греб, ранее также «темница, тюрьма» (СРЯ 15: 198-199), болг. диал. по́греб «угощение после похорон; перекопка виноградника осенью» (БЕР 5: 426), пол. pogrzeb «похороны», чеш. pohřeb «похороны», чак. pögrep «похороны» (Kalsbeek 1998: 523). В словенском и штокавском мы находим формы, продолжающие *pogrëbъ: слвн. pogrëb «похороны», шток. pògreb «похороны», но в этих формах ударение, вероятно, вторично. Конечно, мы не можем быть до конца уверены, что в данном случае мы не имеем дело с поздними независимыми образованиями, однако широкая распространённость континуантов этого слова, а также сходство в семантике, позволяют спроецировать его на прауровень.

Третья версия была выдвинута в 1905 году Ф. Зольмсеном (Solmsen 1905: 443-444). Она связывает славянское и балтийское слова с основой *pelH-, омонимичной *pel(H)- «гореть», и довольно популярна в литературе (Pokorny 1959: 802; Bezlaj 3: 25; Snoj 2016: 529-530; ESJS 11: 683). Ларингал Н постули-

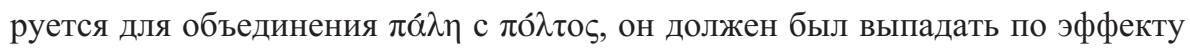
Соссюра (Beekes 2010: 1220).

К дериватам от этой основы относят:

- $\quad * p_{o} l H-e h_{2}>$ греч. $\pi \alpha ́ \lambda \eta$ «мелкая мука, мелкая пыль», с редупликацией $\pi \alpha \imath \alpha \dot{\alpha} \lambda$ «мука тончайшего помола». Альтернативная версия выводит от $\pi \alpha ́ \lambda \lambda \omega$ «размахиваю, потрясаю, раскачиваю; прыгаю, скачу; трясусь,

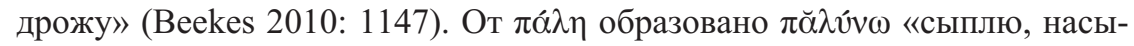
паю» (Beekes 2010: 1148-1149);

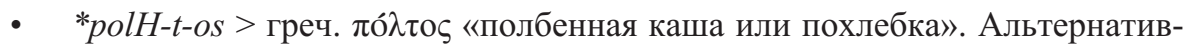
ная версия выводит от $\pi \alpha ́ \lambda \lambda \omega$. Согласно ещё одной этимологии, это субстратное слово (Beekes 2010: 1220);

- *polH-n-> лат. pollen (G. pollinis) «мука самого мелкого помола; пыль, порошок»;

- $\quad$ *polH-t-s> лат. puls (G. pultis) «крутая похлёбка или каша из полбы»; или родственно pollen, или заимствовано из греч. ло́ $\lambda \tau$ ऽ «полбенная каша или похлебка», или вместе с $\pi$ ó $\tau$ бо является субстратным заимствованием (de Vaan 2008: 498); 
- *polH-w-is > лат. pulvis «пыль, мелкий песок; порошок; пепел (покойника)»;

- $\quad$ *plH-> лат. palea «мякина, высевки; солома; шлак»;

- санскр. pálalam «болото, трясина; толчёный кунжут»;

- $\quad$ *pelHus (f.) > санскр. palávvah «мякина», лит. pẽlūs «полова» (m.f. pl; в современном литературном языке употребляется вторичная -о-основа pelaĩ), лтш. pęlus (f. pl.) «полова», прусск. pelwo (nom.sg. f.) «полова», праслав. (*pelus $>$ ) *pelwa «полова».

Иногда к этому же этимологическому гнезду причисляют лат. pello «бью, толкаю», однако pello выводится из п.-и.-е. *pl-n(e)- $h_{2}$ - 'to approach' и не является однокоренным с pollen (de Vaan 2008: 455-456).

На основании перечисленных выше соответствий даже пытаются реконструировать п.-и.-е. *pel- «пыль, мука» (Rejzek 2001: 488; Skok 2: 638). В этом случае этимологическим значением *pepelъ является «мелкий порошок» (Králik 2015: 458).

На якобы смешение семантики «подгорелый» и «изделие из муки» указывает Этымалагічны слоўнік беларускай мовы, приводя в пример бел. naдnaлак, падпалонік, паляніц̧а, пеляніца и пол. podpłomyk - все обозначают лепёшку, испечённую на камнях или на сковороде (ЭСБМ 9: 281). Однако очевидно, что обозначение мучного изделия как «подгоревшего» и образование обозначения пепла от названия муки, имеют мало общего.

А. Баньковский присоединяется к данной версии, но при этом совершенно необоснованно привлекает ещё гомеровское $\pi \varepsilon \hat{\lambda} \omega$ «я двигаюсь» (на самом деле восходящее к * $k^{w} e l H$ - (Beekes 2010: 1168-1169)), реконструируя эклектическое этимологическое значение «пыль, поднимающаяся вверх на ветру» (Bańkowski 2: 699-700).

Наконец, М. Фасмер объединяет 1 и 3 версию в одну, считая это всё производными от одного корня (Фасмер 3: 234).

Четвёртой версией можно назвать трактовку С. А. Старостина, который восстанавливал для праиндоевропейского в значении «пепел» *pel-, coпоставляемое с прауральским *pelme, пракартвельским *perpl- и пралтайским *polńe (все со значением «пепел») (Старостин 2007: 807). Таким образом, в отличие от трёх вышеперечисленных версий, утверждается, что праслав. *pepelъ / *popelъ coхранило исконную праиндоевропейскую и праностратическую семантику этого корня. С. Л. Николаев дополняет это сопоставление прадравидским *pul- «серый» и эскимосо-алеутским *palqә «пепел, жаркий, сухой», на индоевропейском уровне присоединяясь к этимологии Зольмсена, и реконструируя основу *pelə- / *ple- «пыль, пепел» (Nikolaev 2012). 
4.1 Следует признать маловероятным, чтобы праслав. *pepelъ / *popelъ и прабалт. *pelen- сохранили исконное праиндоевропейское или даже праностратическое значение «пепел» в свете того, что для праиндоевропейского в этом значении уверенно реконструируется *heHs-, а для прауральского *kaj'ma (Касьян, Живлов, Старостин 2014: 397). Основанием для такой п.-и.-е. реконструкции служат хеттск. ḩā̌šs- «пепел; пыль; мыло», санскр. ásah «пепел; мелкая пыль», ормури yānak «пепел», п.-герм. *asjōn- «мыльный камень» (> др.-сканд. еsja «мыльный камень», д.-в.-н. essa «горн») (Kloekhorst 2008: 318-319; Mayrhofer 1992: 182-183; Kroonen 2013: 38). Наличие *h eHs- в значении «пепел» как в анатолийской группе, так и в «узкоиндоевропейском», - чрезвычайно весомый аргумент в пользу того, что именно это слово было основным обозначением «пепла» на древнейшей реконструируемой стадии истории праиндоевропейского языка.

Учитывая несводимость праславянской и прабалтийской форм друг к другу и их морфологическую производность, крайне сложно представить, чтобы они представляли собой реликт ностратической древности. Гораздо проще предположить, что праиндоевропейское *pel(H)- «гореть» или *pelH- «мелкая пыль» (в зависимости от выбранной этимологии) действительно может быть связано с вышеперечисленными корнями других ностратических языков, но при этом в случае *pepelъ / *popelъ и *pelen- мы имеем дело с циклическим изменением значения (п.-ностр. «пепел»> п.-и.-е. «гореть»> п.-сл. и п.-балт. «пепел» в одной версии и п.-ностр. «пепел» > п.-и.-е. «мелкая пыль» > п.-сл. и п.-балт. «пепел» в другой).

4.2 Если придерживаться второй версии и считать *popelъ приставочным образованием, то возникает необходимость объяснить вокализм формы *pepelъ, для чего обычно привлекается межслоговая ассимиляция гласных (Miklosich 1886: 235; Соболевский 2006: 275; Преображенский 2: 37). Примеры межслоговой ассимиляции $o>e$ известны по старославянским памятникам. Так, Мейе приводит следующие случаи: заматоръти - заматєрђти «состариться»; оудолњти оудельти «победить, одолеть»; ст.-сл. дєсити - др.-руск. досити «найти» (Meillet 1902: 115-116). Правда, происхождение *pepelъ он склонен объяснять иначе: *pepelъ якобы возникло из *popelъ, поскольку последняя форма стала осознаваться как редуплицированная (Meillet 1902: 116). Такое толкование Мейе однако ничем не подкрепляет.

Вайан приводит следующие примеры ассимиляции: ст.-сл. дєбрђє «лучше» при обычном добрњє (ограничено Зогр., где дєбрњє встречается 3 раза, а добрњє 6 раз (SJS 1: 497)), грєбиште «могила» (Зогр.) при гробиште, одєльти и одольти «победить», болг. надделе́я «превосхожу, преобладаю» и болг. диал. надоля́ «одерживаю верх», ст.-сл. чєтворо и русск. четверо (Vaillant 1950: 193-194). 
А. И. Соболевский считал случаями межслоговой ассимиляции $о>e$ пары велет - волот, Велес - Волос, лебеда - лобода, лепетать - лопотать, пелена - чеш. polona (Соболевский 2006: 275).

Однако в форме заматеръти не обязательно видеть ассимиляцию, здесь вполне можно усмотреть аналогию с производящей основой *mati (G. *mate$r e)$. Архаичный глагол дєсити - досити вполне может отражать две ступени древнего аблаута, грєбиштє и гробиштє также не являются показательным примером. Скорее всего, первое является производным непосредственно от глагола *gresti, а второе - от существительного *grobъ (ЭССЯ 7: 109, 132). Расхождение между *četworo и *četwero также скорее напоминает последствие выравнивания аблаута (ЭССЯ 4: 93-94). Пара лепетать - лопотать является звукоподражательной по происхождению (ЭССЯ 14: 125-127; 16: 6162). Что касается прочих пар, приводимых Соболевским, то они отличаются друг от друга не одним гласным, а двумя, поэтому Соболевский привлекал двухступенчатое объяснение, он полагал, что слова в этих парах изначально отличались вокализмом второго слога, а гласный первого слога был позднее ассимилирован (Соболевский 2006: 276). Учитывая большие сложности с этимологией этих слов, правильность данной гипотезы остаётся под вопросом.

Тем не менее, помимо добрњє - дєбрњє и глаголов, производных от *dols, мы располагаем и другими образцами межслоговой ассимиляции. Хороший пример перехода о $>\mathrm{e}-$ русск. ребёнок (в говорах сохранилось исходное робёнок) < *orbe. Менее надёжным является русск. теперь (диал. топе́ре и топе́pвво), чешск. teprve < *to pbrwo (есть и другие версии). Обращает на себя внимание тот факт, что как и в слове *pepels, в обоих примерах ассимилированный гласный находится перед губным.

Распространено это явление в русских фамилиях, образованных от

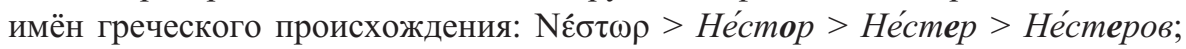

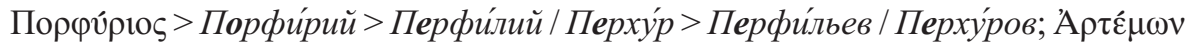
$>$ Артемо́н > Артамо́н > Артамо́нов; Гєра́бцо > Гера́сим / Гара́ссим > Гера́симов / Гара́симов; $\Sigma \varepsilon \beta \alpha \sigma \tau \imath \alpha$ о́ $>$ Севастья́н / Севостья́н > Севастья́нов / Савостья́нов (Унбегаун 1989: 48).

Межслоговой ассимиляции и диссимиляции в истории русского языка подвергались и другие гласные: татива > тетива, съдыти > cuдеть. Широко это явление для разных гласных распространено в русских говорах (Пауфошима 1983: 43-47).

Примеры межслоговой ассимиляции также можно найти в македонских (чему > чуму) (Видоески 1999: 158) и словенских говорах (Дуличенко 2005: 204).

Однако во всех процитированных выше примерах, включая, по-видимому, македонский, безударный гласный ассимилируется ударному, в отличие от *popelъ / *pepelъ, где гласный первого слога является ударным. 
Потенциальным примером ассимиляции ударного гласного можно считать праславянское название лебедя, если принимать реконструкцию форм *elbędb / *elbedb / *olbędb, выводимых из *alb ${ }^{h}$ (ЭССЯ 6: 18-19; 32: 50). Тем не менее, такая реконструкция сталкивается с рядом сложностей формального характера (Derksen 2008: 365-366), что не позволяет считать её вполне показательным случаем.

Единственным надёжным найденным нами примером ассимиляции удар-

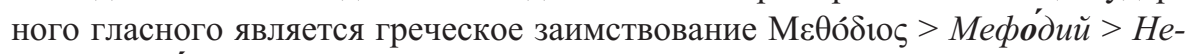
фёд / Нефе́дий > Нефёдов / Нефедьев (Унбегаун 1989: 48). Но заимствование всё же не может выступать в роли полноценной аналогии для исконной лексики (кроме того, в случае данного имени можно подозревать влияние более распространённого Фёдор), так что вопрос о возможности межслоговой ассимиляции ударного гласного в праславянской лексике остаётся открытым.

Немаловажно также то, что существительные с *po- и значением результата действия, скорее всего, вторичны по отношению к глаголам. Прототипическими значениями для *ро- является значения начала действия (хорошо сохраняется в глаголах движения) и малой степени протекания действия. При становлении категории вида в праславянском из значения начала действия развивается перфективное значение, и * ро- начинает активно использоваться для создания видовых пар. Таким образом, результативное значение субстантивного *ро- обязано было прийти из сферы глагольного словообразования. Существительные с *po- и значением результата действия могли начать появляться только на этом, сравнительно позднем, этапе. Следовательно, для приставочной гипотезы образования формы *popelъ важно наличие промежуточного звена в виде перфективного глагола (если, конечно, не допускать, что данная модель была столь частотной и продуктивной, что существительные могли образовываться напрямую от глагола несовершенного вида без промежуточного звена). В то же время, славянские образования, теоретически имеющие шанс восходить к *pepeliti / *popeliti, являются глаголами несовершенного вида и скорее сами образованы от *pepelъ / *popels, чем наоборот.

4.3 Исключив вторую и четвёртую этимологии, перейдём к рассмотрению версий, предполагающих первичность формы *pepels, образованной посредством частичной редупликации от корня *pel(H)- или *pelH-. Форма *popels, согласно этим версиям, считается возникшей под влиянием соотнесения с приставкой *po- по народной этимологии (Брандт 1890: 290).

Брандт зашёл так далеко, что даже сопоставлял эту редупликацию с частичной редупликацией в праиндоевропейском перфекте и считал, что *pepels - этимологически перфектное причастие от утраченного глагола *pelti c внутренней формой «сгоревшее» (Брандт 1890: 291), что, конечно, является 
анахронизмом. Кроме того, сейчас мы знаем, что в формах редуплицированного перфекта для второго слога был характерен гласный -о- (или нулевая ступень), а случаи вроде приводимого Брандтом в качестве аналогии $\pi \lambda \eta \dot{\theta} \omega$ - $\pi \varepsilon \dot{\pi} \lambda \eta \theta \alpha$ объясняются наличием ларингала.

Частичная редупликация активно использовалась в праиндоевропейском, некоторые реликты сохранились в праславянском: *bobrъ / *bebrъ / *bbbrъ «бобр» (ЭССЯ 1: 174-175; 2: 145-146; 3: 159); *wewerbka / *wewerica «белка»; формы глагола *dati «дать». Однако непосредственно в праславянском частичная редупликация обычно была сопряжена с ономатопеей: *gogolb / *gogolb название водоплавающей птицы (ЭССЯ 6: 193-194); *kočetъ / *kokotъ «петух» (ЭССЯ 10: 106, 117-118); *teterwb «тетерев»; *boba / *bobь- обозначение круглых предметов (ЭССЯ 2: 142, 149); *čečera / *čečetъ - название птицы (ЭССЯ 4: 32, 33); *lola - обозначение неряхи, проказника, долговязого или глупого человека (ЭССЯ 16: 11).

Единственный известный нам пример частичной редупликации, вероятно, не связанный с ономатопеей, - это глагол *čečeriti «ерошить волосы», образованный от *čeriti (ЭССЯ 4: 32-33). Однако стоит отметить, что континуанты *čečeriti представлены только в чешском и словацком, поэтому не вполне ясно, насколько мы можем считать эту форму праславянской.

Важно отметить, что слово *xoxolb, иногда приводимое как пример частичной редупликации, скорее всего, вовсе не является таковой (ЭССЯ 8: 54-55).

В отличие от частичной полная редупликация в праславянском могла быть не связана с ономатопеей: *melti $>$ *molmolb с неясным значением (ЭССЯ 19: 190); *perti «лететь» > *porporъ «флажок»; *poléti > *polpolati «пылать» (хотя немалое количество слов с полной редупликацией также ономатопоэтического происхождения: *golgols (ЭССЯ 6: 205); *kolkolb (ЭССЯ 10: 137-139); *bobbnъ / *bobbno (ЭССЯ 2: 232-233), *totъnъ; *pelpelъ «перепел»; *bolbolb, *bolboliti (ЭССЯ 2: 170-171); *xorxoriti se (ЭССЯ 8: 73); *tortoriti; *gognati «гнусавить» (ЭССЯ 7: 81-82), *dbrdoriti (ЭССЯ 5: 220)). К случаям полной редупликации следует, видимо, также отнести звукоподражательные глаголы *bobotati (ЭССЯ 2: 143), *gogotati (ЭССЯ 6: 194-195), *xoxotati (ЭССЯ 8: 55), *kokotati (ЭССЯ 10: 117), *lolotati (ЭССЯ 16: 11), *momotati (ЭССЯ 19: 208), в составе которых -t- является вставным элементом, необходимым для морфологического оформления слова.

Таким образом, *pepelъ является чуть ли не уникальным примером частичной редупликации в незвукоподражательном существительном.

4.4 Праславянское *pepelъ трудноотделимо от лит. pẽlenas «костёр, очаг», pelenaĩ (pl.) «пепел»; лтш. pęlns «костёр», pèlni (pl.) «пепел»; прусск. pelanne (f.) «пепел», pelanno (f.) «очаг». 
Сюда же часто относят лит. plénys «горячие угли, горячий пепел, пламя; пепелище», лтш. plẽnes «белый пепел, налёт на углях», прусск. plieynis «хлопья пепла». Однако В. Смочинский считает, что это невозможно в силу корневого вокализма (Smoczyński 2007: 472-473). Сюда же относится русское плень «гниль» (Фасмер 3: 279).

Основ мужского рода с суффиксом -en- в литовском немного. Помимо pẽlenas Отрембский называет следующие примеры: gluodùs «гладкий»> gluodẽnas «ломкая веретеница» (Anguis fragilis); vélti «валять»> vẽlenas «вал»; duobẽ «яма»> Dúobenas - название озера; skirsti «трескаться, лопаться» > Skirtenas - название реки (Otrębski 2: 177). Однако словообразовательная модель с суффиксом -enженского рода весьма продуктивна. Следует особо отметить наличии большого количество отглагольных производных обозначающих результат какого-то разрушающего действия: ižti «лущиться, трескаться» > ižena «шелуха, кожура»; lúžti «ломаться»> líženos (pl.) «обломки»; pjáuti «пилить» > pjùvenos (pl.) «опилки»; púti «гнить»> pùvenos (pl.) «перегной»; svilti «подгорать»> sviltenos (pl.) «пригар»; krekéti «свёртываться»> krẽkenos (pl.) «молозиво» (Otrębski 2: 178). Слово pelenaĩ прекрасно укладывается в эту модель, выделяясь только родом. Сам производящий глагол, однако, в балтийских языках был утерян.

4.5 Параллели из других языков показывают, что значение «пепел» могло развиваться как на основе глагола «жечь» или «гореть», так и у слова «пыль». Первую ситуацию можно проиллюстрировать греческим $\tau \dot{\varepsilon} \varphi \rho \alpha$ «пепел» < ${ }^{*} d^{h} e g^{w h}$ - «жечь» (Beekes 2010: 1475).

Сдвиг «пыль» > «пепел» показывают лат. cinis «пепел» и алб. hi «пепел» (<*skina (Orel 1998: 147)), которые восходят к тому же корню, что и греч. кóvis «пыль, песок, прах; пепел: щёлочь», а также тох. Б kentse «пыль» (de Vaan 2008: 115). Кроме того, можно привести лат. pulvis «пыль, мелкий песок; порошок; пепел (покойника)» и, видимо, происходящие от того же корня валл. ulw и шотл. ulbhach (Macbain 1911: 88).

Следовательно, типологические параллели не дают нам аргументов в пользу какой-либо из версий.

4.6 Таким образом, первая версия включает в себя следующие положения:

- в прабалтославянском существовал континуант корня *pel(H)- «гореть»;

- $\quad$ в праславянском этот корень был тематизирован в виде *polěti, а в прабалтийском со временем утрачен;

- $\quad$ в праславянском от этого корня было при помощи частичной редупликации образовано слово *pepelъ «пепел»;

- в прабалтийском от этой же корня по продуктивной модели был образован суффиксальный дериват *pelenas «пепел». 
- Третья версия предполагает следующее:

- в праиндоевропейском имелся корень *pelH-, обозначавший мелкую пыль или нечто подобное;

- $\quad$ эта основа в нерасширенном суффиксами виде долгое время сохранялась в праславянском, однако в конечном итоге была утрачена;

- $\quad$ в праславянском от неё было при помощи частичной редупликации образовано слово *pepelъ «пепел»;

- глагол *poléti с этой основой не связан;

- прабалтийское *pelenas «пепел» с этой основой также не связано.

Практически каждое из перечисленных допущений третьей версии вызывает определённые сомнения. Предполагаемые дериваты от основы *pelH- «мелкая пыль» в греческом, латыни и санскрите плохо сводимы друг к другу как формально, так и семантически, зачастую они имеют альтернативную этимологию. В праславянском и прабалтийском нет никаких следов бессуфиксальных дериватов от этой основы, при том, что корень *pel(H)- «гореть» представлен в праславянском в виде продуктивного словообразовательного гнезда. Отделение п.-сл. *pepelъ от п.-балт. *pelenas также выглядит сомнительным. Известны и другие случаи, когда в праславянском и прабалтийском разноструктурные дериваты от одной основы получали идентичное значение. Ярким примером является п.-сл. *bělъ и п.-балт. *baltas «белый» (Саенко 2012).

В связи с этим следует сказать, что первая версия выглядит гораздо более крепко стоящей на ногах. Третья версия предполагает целый ряд допущений, каждое из которых не является невозможным, но их совокупность делает гипотезу довольно маловероятной.

Отдельно следует оговорить объединение первой гипотезы с третьей, при которой *pel(H)- «гореть» и *pelH- «мелкая пыль» сводятся к одному корню. При этом нужно признавать первичность *pelH- «мелкая пыль», выходящего за рамки балто-славянской группы, считать балто-славянское «пепел» связующим звеном между значениями «мелкая пыль» и «гореть», а в самом *pel(H)- «гореть» видеть позднее собственно славянское производное от «пепла». Либо напротив приходится видеть в *pel(H)- «гореть» древний реликт (ср. ностратические параллели, приводимые С. А. Старостиным), сохранившийся только в славянском, a *pelH- «мелкая пыль» полагать дериватом, образованным от *pel(H)- «пепел». В первом случае нам нужно признать ностратические параллели к *pel(H)- «гореть» случайным совпадением (что на наш взгляд куда хуже признания случайным совпадением сходства *pel(H)«гореть» и *pelH- «мелкая пыль»), а во втором, как и для версии Старостина требуется признания праиндоевропейской древности корня *pel(H)- в значении «пепел», для чего, как мы уже выяснили, нет оснований. 
5. Любое решение в такой сложной ситуации, как вышеописанная, носит вероятностный характер, поэтому, даже учтя все аргументы мы не можем окончательно отвергнуть ни одной из приведённых версий. Можно только попытаться определить, какая из них меньше всего противоречит фактам.

Мы полагаем, что наименее вероятной является версия С. А. Старостина, которая видит в п.-слав. *pepelъ и п.-балт. *pelenas архаизм ностратической древности. Производность этих форм, а также достаточно надёжная реконструкция праиндоевропейского обозначения пепла как $* h_{2} e H_{s-}$, делают возможность такого развития событий довольно эфемерной и нарушающий введённый самим же Старостиным принцип ступенчатой реконструкции.

Если не будет найдено фактов, показывающих возможность межслоговой ассимиляции ударного гласного безударному в праславянском, следует считать маловероятной версию, выводящую *popelъ от *pel(H)- «гореть» с приставкой *ро-.

Слабой стороной оставшихся двух версий, является то, что они исходят из наличия частичной редупликации в незвукоподражательном существительном, что не было характерно для праславянского. Если мы всё же допустим, что это было возможно, и будем вынуждены выбирать между деривацией от *pel(H)- «гореть» и *pelH- «мелкая пыль», то, как было показано ранее, первая версия предполагает значительно меньшее количество недоказуемых допущений. Это заставляет нас заключить, что, скорее всего, п.-слав. *pepelъ является производным от глагола (*pel->) *poléti.

\section{Библиография}

Брандт, Роман Ф. 1890. Дополнительные замечания к разбору этимологического словаря Миклошича. Русский филологический вестник, 23: 289-305.

БЕР 5 = Дуриданов, Иван et al. 1999. Български етимологичен речник. 5. София: Издателство на Българската Академия за науките.

Видоески, Божидар. 1999. Дијалектите на македонскиот јазик. 3. Скопје: Македонска Академија на науките и уметностите.

Видоески, Божидар. 1994. Македонските дијалекти во Егејска Македонија (Обид за класификација). In Македонскиете дијалекти во Егејска Македония, 23-60. Скопје: Македонска Академија на науките и уметностите.

ГСБМ 24 = Булыка, Аляксандр M. et al. 2005. Гістарычны слоўнік беларускай мовы. 24. Мінск: Беларуская навука.

ДС 1969 = Оссовецкий, Иосиф A. et al. 1969. Словарь современного русского народного говора (д. Деулино Рязанского района Рязанской области). Москва: Наука.

Касьян, Алексей С. Живлов, Михаил А. Старостин, Георгий С. 2014. Вероятностная оценка индоевропейско-уральского родства: формализованное сравнение реконструированной базисной лексики. In Индоевропейское языкознание и классическая филология - XVIII: 382-408. Санкт-Петербург: Наука. 
ОЛА = Вендина, Татьяна И. Калнынь Людмила Э. 2011. Общеславянский лингвистический атлас, фонетико-грамматическая серия. Выпуск 6. Рефлексы *е. Москва: ИРЯ РАН.

Пауфошима, Розалия Ф. 1983. Фонетика слова и фразы в севернорусских говорах, Москва: Наука.

Преображенский, Александр Г. 1910-1914. Этимологический словарь русского языка. 2. Москва: Типография Г. Лисснера и Д. Совко.

Саенко, Михаил Н. 2012. Реконструкция этимологического значения праслав. *bělъ. In Северное Причерноморье: к истокам славянской культуры: 56-59. Киев - Москва - Феодосия.

Соболевский, Алексей И. Мелкие заметки по славянской и русской фонетике. In Tpydы no истории русского языка, 2: 266-290. Москва: Языки славянских культур.

СРЯ 15 = Богатова, Галина А. et al. 1989. Словарь русского языка XI-XVII вв. Выпуск 15. Москва: Наука.

СРНГ = Филин, Федот П. 1965-2016. Словарь русских народных говоров. Выпуски 1-49. Санкт-Петербург: Наука.

Старославянский словарь = Цейтлин, Раля М. et al. 1994. Старославянский словарь, Москва: Русский язык.

Старостин, Сергей А. 2007. Indo-European among other language families: problems of dating, contacts and genetic relationships. In Tруды по языкознанию: 806-820. Москва: Языки славянских культур.

Унбегаун, Борис О. 1989. Русские фамилии. Москва: Прогресс.

Фасмер, Макс. 1964-1973. Этимологический словарь русского языка. Москва: Прогресс.

Цейтлин, Раля М. 1977. Лексика старославянского языка. Москва: Наука.

ЭСБМ 9 = Цыхун, Генадзь А. et al. 2004. Этымалагічны слоўнік беларускай мовы. 9. Мінск: Беларуская навука.

ЭССЯ = Трубачёв, Олег Н. et al. 1974-2016. Этимологический словарь славянских языков. 1-40. Москва: Наука.

Bańkowski, Andrzej. 2000. Etymologiczny stownik języka polskiego. I-II. Warszawa: PWN.

Beekes, Robert S. P. 2010. Etymological Dictionary of Greek. Leiden - Boston: Brill.

Bezlaj, France. 1995. Etimološki slovar slovenskega jezika. 3. Ljubljana: Mladinska knjiga.

Boryś, Wiesław. 2005. Słownik etymologiczny języka polskiego. Kraków: Wydawnictwo Literackie.

Boryś, Wiesław. 2007. Etymologie stowiańskie i polskie. Warszawa: Slawistyczny ośrodek wydawniczy.

Derksen, Rick. 2008. Etymological Dictionary of the Slavic Inherited Lexicon. Leiden - Boston: Brill.

Dobrowsky, Joseph. 1822. Institutiones linguae slavicae dialecti veteris. Vindibona: Antonii Schmid, c. r. p. typographium.

ESJS 11 = Erhart, Adolf et al. 2002. Etymologický slovnik jazyka staroslovenského. 11. Praha: Academia.

Fonološki opisi = Ivić, Pavle et al. 1981. Fonološki opisi sprskohrvatskih/hrvatskosrpskih, slovenačkih i makedonskih govora obuhvaćenih obšteslovenskim lingvističkim atlasom. Sarajevo: Minerva.

Ivančič Kutin, Barbara. 2007. Slovar bovškega govora. Ljubljana: Založba ZRC SAZU.

Kalsbeek, Janneke. 1998. The Čakavian Dialect of Orbanići near Žminj in Istria. Amsterdam Atlanta: Rodopi.

Kloekhorst, Alwin. 2008. Etymological Dictionary of the Hittite Inherited Lexicon. Leiden Boston: Brill. 
Králik, L’ubor. 2015. Stručný etymologický slovník slovenčiny. Bratislava: Veda.

Kroonen, Guus. 2013. Etymological Dictionary of Proto-Germanic. Leiden - Boston: Brill.

Machek, Václav. 1968. Etymologický slovnik jazyka českého. Praha: Nakladatelství Československé Akademie Věd.

Mayrhofer, Manfred. 1992. Etymologisches Wörterbuch des Altindoarischen. I. Heidelberg: Carl Winter Universitätsverlag.

Macbain, Alexander. 1911. An Etymological Dictionary of the Gaelic Language. Stirling: Eneas MacKay.

Meillet, Antoine. 1902. Études sur l'étymologie et le vocabulaire de vieux slave. Paris: Librairie Émille Bouillon.

Miklosich, Franz. 1886. Wörterbuch der slavischen Sprachen. Wien: Wilhelm Braumüller.

Nikolaev, Sergey L. The Indo-European etymology. http://starling.rinet.ru/cgi-bin/query.cgi?roo $\mathrm{t}=$ config\&morpho $=0 \&$ basename $=\mid$ datalie $\mid$ piet, вход 20.02.2017.

Orel, Vladimir. 1998. Albanian Etymological Dictionary. Leiden - Boston - Köln: Brill.

Otrębski, Jan. 1958. Gramatyka języka litewskiego. Warszawa: PWN.

Pokorny, Julius. 1959. Indogermanisches etymologisches Wörterbuch. Bern - München.

Rejzek, Jiří. 2001. Český etymologický slovnik. Brno: Leda.

Skok, Petar. 1971-1973. Etimologijski rječnik hrvatskoga ili srpskoga jezika. Zagreb: Štamparski zavod Ognjen Priča.

Smoczyński, Wojciech. 2007. Stownik etymologiczny języka litewskiego. Wilno: Printer Polyglot.

Snoj, Marko. 2016. Slovenski etimološki slovar. Ljubljana: Založba ZRC.

Solmsen, Felix. 1905. Beiträge zur Geschichte der lateinischen Sprache. Zeitschrift für vergleichende Sprachforschung auf dem Gebiete der Indogermanischen Sprachen, 38. Bd., 4. H.: 437-458.

SJS = Kurz, Josef et al. 1958-1983. Slovnik jazyka staroslověnského. Praha: Nakladatelství Československé Akademie Věd.

de Vaan, Michiel. 2008. Etymological Dictionary of Latin and the other Italic Languages. Leiden - Boston: Brill.

Vaillant, André. 1950. Grammaire comparée des langues slaves. Tome I. Phonétique. Lyon: Editions IAC.

Prispelo februarja 2017, sprejeto aprila 2017.

Received February 2017, accepted April 2017. 


\section{Praslovanska *pepelъ/*popelъ: izhodiščna oblika in etimologija}

V prispevku obravnavamo zemljepisno razširjenost in zgodovinski razvoj praslovanskega *popels in *pepels v slovanskih jezikih. Analiza slovanskega gradiva izkazuje, da je oblika * popels etimološko sekundarna. Nastala je na podlagi ljudske etimologije oblike *pepels, pri kateri je bil prvi zlog interpretiran kot predpona *po-, značilna za izglagolske izpeljanke, ki imajo pomen rezultata dejanja (*pometъ, *pogrebъ).

Opozarjamo na pomankljivosti nostratične hipoteze o izvoru obravnavane praslovanske oblike - hipoteza je ovržena zaradi anahronistične izpeljave, na kateri ta sloni. Izmed dveh preostalih hipotez, ki etimologijo praslovanskega *pepels povezujejo z delno podvojitvijo korena (od *pel(H)- »goreti« in *pelH- »fini prah, moka «), se nam zdi prva verjetnejša, saj je v manjši meri v nasprotju z gradivom in je njena rekonstrukcija bolj dokazljiva.

\section{Proto-Slavic *pepelъ/*popelъ: Original Form and Etymology}

The article is dedicated to the geographical spread and the historical development of Proto-Slavic *popels and *pepels in the Slavic languages. The analysis of the data shows that the form *popelb should be regarded a derivative of *pepelb. The former appeared as a result of the folk etymology where the first syllable was reanalysed as the prefix * ${ }^{*}$ - used for the formation of deverbal nouns denoting a result (*pometz, *pogrebr).

The Nostratic version also has to be rejected because of its anachronic sequence of events. From the remaining two etymologies, which suggest the partial reduplication (from *pel(H)- 'burn' and *pelH- fine dust' accordingly), the author considers the first one more plausible as it doesn't contradict the data as much as the second one and contains fewer unprovable assumptions. 